\title{
Fast science, neoliberalne reżimy produktywności oraz technologie ICT: Uniwersytet w czasach pandemii COVID-19
}

\section{Abstract \\ Fast Science, Neoliberal Regimes of Productivity and ICT Technologies: Academy in the Era of COVID-19 Pandemic}

The goal of the article is to answer the following question: what does the pandemic of COVID -19 reveal in the context of the discussion dedicated to the ways of the functioning of the academy today? Therefore the subject of the analysis is not the disease itself nor its cultural meanings, but the phenomena that, although present before the pandemic outbreak, became far more clear, perceptible and acutely experienced. In the article, our interest is focused on the increase of the pace of virtual social interactions, the speed of information transfer, the enhancement of academic regimes of productivity, the surplus of knowledge generated within the fields of humanities and social sciences and the role of information and communications technologies played in these processes. The main argument is that, the pandemic of COVID-19 shows how, in the context of the academy, the entire logics of late capitalist social relations and neoliberal governing of social subjects is focused.

Keywords: COVID-19 pandemic, academy, neoliberal governmentality, late capitalism, regimes of productivity, fast science, information society, ICT technologies 
Informacja niczym epidemia szerzy się we wszystkich dziedzinach (Eriksen 2003: 39).

Łatwość komunikacji wraz z nadmiarem informacji stanowią najpoważniejsze zagrożenie dla ludzkich mechanizmów obronnych (Baudrillard 2009: 84).

\section{Działanie zaczepne}

Celem prezentowanego artykułu - inspirowanego przywołanymi powyżej fragmentami zaczerpniętymi z wpływowych książek będących krytyką społeczeństwa informacyjnego: Tyranii chwili Thomasa Hyllanda Eriksena (2003) oraz Przejrzystości zła Jeana Baudrillarda (2009) - jest próba zmierzenia się z następującym zagadnieniem: co ujawniła (wyostrzyła czy też naświetliła) pandemia COVID-19 w kontekście dyskusji dotyczącej współczesnego sposobu funkcjonowania Uniwersytetu ${ }^{1}$ ?

Zanim jednak rozstrzygniemy ten problem, chcielibyśmy wyjaśnić samo pytanie. W tym też celu w pierwszej kolejności odniesiemy się do kwestii terminologicznych. W licznych dyskusjach pojawiających się w przestrzeni wirtualnej funkcjonują rozmaite sformułowania, których celem jest zdefiniowanie obecnego stanu rzeczy ${ }^{2}$. Wśród nich najczęściej napotykanymi są „pandemia” oraz „zaraza”. Znaczenia, jakie słowa te konotują, nie są ze sobą tożsame i ewokują odmienne przestrzenie skojarzeniowe. Różnice pomiędzy nimi wydają się nam na tyle istotne, że niezbędne staje się bardziej szczegółowe wyjaśnienie ich treści i sensów. Wybór konkretnych metafor i wyrażeń językowych nie pozostaje przecież bez wpływu na proces interpretacji zjawisk oraz to, jak w rezultacie postrzegamy świat. Odzwierciedla także nasz etyczny i polityczny stosunek do otaczającej rzeczywistości, oddolnych i eksperckich dyskursów oraz praktyk społecznych (por. Jenks 1999: 157).

„Zaraza” jest konceptem wysoce zmitologizowanym, zaadaptowanym przez literaturę w celu opowiedzenia o uniwersalnych problemach ludzkich, dla których szalejący pomór stanowi mroczne, kontrastujące tło. Wystarczy przywołać Dżumę Alberta Camusa z jej humanistyczną wymową lub Zarazę Grahama Ma-

${ }^{1}$ Mówiąc o Uniwersytecie, mamy na myśli asamblaż idei leżących u podstaw społecznego funkcjonowania tej instytucji oraz rzeczywistych praktyk podmiotów społecznych.

2 Pisząc o „obecnym stanie rzeczy”, mamy na myśli okres od 11 marca 2020 r. (tj. dnia, w którym Światowa Organizacja Zdrowia ogłosiła, że COVID-19 może zostać scharakteryzowany jako pandemia) do 31 maja 2020 r. (tj. dnia, w którym przypadał termin składania artykułów do niniejszego numeru „Prac Etnograficznych”). Informacja ta wydaje się również znacząca z punktu widzenia przedstawionych w artykule rozpoznań dotyczących problemu fast science. Jest to jednocześnie czas obowiązywania w Polsce najbardziej restrykcyjnych obostrzeń wynikających z rozprzestrzenianiem się wirusa SARS-CoV-2. 
stertona $\mathrm{z}$ jej zatrważającym finałem. Słowo „zaraza” ma tym samym tendencję do mitologizowania doświadczenia. Z perwersyjną chlubą będziemy mogli kiedyś powiedzieć - jeśli przeżyjemy - że „nam też zdarzyło się żyć, kochać, spać, jeść w czasach zarazy" (sformułowanie to jest nawiązaniem do klisz narracyjnych stosowanych $\mathrm{w}$ ostatnich miesiącach $\mathrm{w}$ przestrzeni medialnej, które powielają, na własny użytek, tytuł słynnej książki Gabriela Garcíi Márqueza). I choć zgadzamy się $\mathrm{z}$ twierdzeniem, że proces doświadczania rzeczywistości ma $\mathrm{w}$ dużej mierze charakter narracyjny, to nie czujemy się bohaterami podobnych opowieści. W naszym doświadczeniu nie ma nic romantycznego, magicznego i przerażającego. Wręcz przeciwnie.

„Zaraza" nie odzwierciedla naszych przeżyć - nie odczuwamy jej na własnej skórze, nikt z naszych bliskich nie umarł, śmierć to liczba na pasku w telewizorze. To, czego na co dzień doświadczamy, to raczej konglomerat efektów ubocznych lockdownu, społecznej izolacji, zdominowany przez poczucie zawrotnego rozszerzania się rzeczywistości o wymiar wirtualny oraz neoliberalne reżimy produktywności, wzbogacone o wymiar afektywny wynikający z niemożności sprostania ich wymogom. W wyjściowym pytaniu decydujemy się więc używać słowa „pandemia”, nie zaś „zaraza”, ponieważ w większym stopniu, jak sądzimy, odzwierciedla ono konteksty, które są przedmiotem prezentowanych przez nas rozważań.

Słowo „pandemia” (pan oznacza „wszyscy”, demos - „ludzie”) wskazuje na globalny aspekt doświadczenia, które w czasach późnego kapitalizmu ujawnia się z całą swoją mocą dzięki kompresji czasu i przestrzeni (por. Harvey 1990) uzyskanej przy użyciu technologii informacyjno-komunikacyjnych (information and communications technology, ICT). Choć przemieszczanie się ludności i zwierząt na duże odległości także w przeszłości sprzyjało rozprzestrzenianiu się patogenów, przyspieszenie, jakie obecnie towarzyszy temu zjawisku, a także możliwość jego nieustannego monitorowania (natychmiastowego reagowania na nie i dzielenia się tym doświadczeniem w skali międzynarodowej), sprawiają, że koncepcja życia w globalnej wiosce wydaje się bardziej aktualna niż kiedykolwiek. Wystarczy chociażby przypomnieć, że Yersinia pestis (pałeczka dżumy), która doprowadziła do śmierci ponad dwustu milionów ludzi, potrzebowała w średniowieczu sześciu lat, aby opanować prawie cały obszar kontynentu europejskiego.

Ów globalistyczny obraz pandemii, w jej późnokapitalistycznym wydaniu, współgra ze zjawiskami, które staramy się sproblematyzować w prezentowanym artykule. Interesuje nas mianowicie gwałtowny wzrost tempa interakcji społecznych o charakterze wirtualnym, szybkość przekazywania informacji, wzmocnienie akademickich reżimów produktywności, nadmiar wytwarzanej wiedzy z zakresu nauk społecznych i humanistycznych oraz rola, jaką w tych procesach odgrywają technologie informacyjno-komunikacyjne. Fenomeny te będziemy analizować w odniesieniu do naszych (tj. autorów prezentowanego tekstu) doświadczeń jako pracowników naukowych. Twierdzimy bowiem, że to właśnie $\mathrm{w}$ indywidualnych doświadczeniach ogniskują się zmiany, jakim w ostatnich 
dekadach podlega Uniwersytet ${ }^{3}$. W Polsce transformacja ta rozpoczęła się wraz $\mathrm{z}$ neoliberalnymi reformami szkolnictwa wyższego realizowanymi w myśl ustaw uchwalonych w 2011 i 2018 r. Należy pamiętać, że działania te nie tylko wiążą się z przekształceniami o charakterze strukturalnym; bo choć postrzega się je jako "nudne, rutynowe i biurokratyczne praktyki, często wywierają głęboki wpływ na życie społeczne". Warunkują one mianowicie wykształcenie się nowych języków, norm, etyk i polityk rządzenia (Shore, Wright 2000: 57-60). Ich rezultatem jest także wytworzenie się nowego typu neoliberalnych podmiotów społecznych, których działania winny być zorientowane na kierowanie (rządzenie) sobą zgodnie z zasadą nieustannego doskonalenia się poprzez zwiększanie własnej odpowiedzialności, efektywności i produktywnościł.

Powtórzmy zatem raz jeszcze wyraźnie: w otwierającym artykuł akapicie pytamy o to, „co ujawniła (wyostrzyła czy też naświetliła) pandemia COVID-19 w kontekście dyskusji dotyczącej współczesnego sposobu funkcjonowania Uniwersytetu". Przedmiotem naszej analizy staje się tym samym nie tyle śmiertelna choroba i jej kulturowe znaczenia, ile fenomeny, które, choć istniały przed pojawieniem się wirusa SARS-CoV-2, stały się za sprawą obecnej sytuacji lepiej dostrzegalne, wyraźniejsze, intensywniej odczuwalne. Pandemia jest tutaj swego rodzaju popsutą migającą jarzeniówką rozświetlającą co jakiś czas ciemne pomieszczenie (tj. Uniwersytet), w którym nauczyliśmy się jakoś po omacku poruszać, potykając się czasami o porozrzucane na podłodze przeszkody. Celem, jaki sobie stawiamy, jest opisanie tego pomieszczenia, a nie źródła światła. Podzielamy w tym zakresie spostrzeżenie Iana M. Cooka (2020), który uznał, że „odpowiedź na koronawirusa, jakiej zobowiązani jesteśmy udzielić, powinna ujawnić ukryte wzorce podtrzymujące nasze [akademickie - przyp. autorów] życia”. Twierdzimy, że w tym, co ujawniła (wyostrzyła i naświetliła) pandemia w kontekście dyskusji na temat współczesnego sposobu funkcjonowania Uniwersytetu, skupia się cała logika późnokapitalistycznych stosunków społecznych oraz neoliberalnego typu zarządzania podmiotami społecznymi.

Dążąc do rozwinięcia powyżej przywołanych myśli w sposób satysfakcjonujący pod względem poznawczym, w artykule będziemy kroczyć śladem wydarzeń sumujących się na doświadczenie, które za Ministrem Zdrowia Łukaszem Szu-

${ }^{3}$ Stosowany tu często zaimek „my” odnosi się zatem głównie do autorów tekstu (jako podmiotów uwikłanych w procesy, które poddają analizie). W innych przypadkach owo „my” ma wymiar polityczny - zachęca czytelnika do zwrócenia uwagi na fakt, że wszyscy, uczestnicząc w procesach neoliberalizacji uniwersytetu, musimy w większym lub mniejszym stopniu się im podporządkować. $\mathrm{W}$ innym razie pozostaje nam jedynie rezygnacja $\mathrm{z}$ uczestnictwa $\mathrm{w}$ dyskursie.

${ }^{4} \mathrm{~W}$ odniesieniu do pracowników akademickich owa postawa powinna (w dużym uproszczeniu) znajdować odzwierciedlenie w umiejętności szacowania i kalkulowania, jakie działania są korzystne z punktu widzenia nakreślonych przez pracodawcę celów (np. publikowanie w wysoko punktowanych czasopismach), jakie zaś nie przynoszą wymiernych korzyści (np. redagowanie tomów pokonferencyjnych). Szerzej na temat postępującego procesu neoliberalizacji Uniwersytetu piszemy w: Songin-Mokrzan 2016, Mokrzan 2019 oraz Songin-Mokrzan, Mokrzan 2020. 
mowskim określić można mianem „czasu kwarantanny dla społeczeństwa” (wypowiedź z 11 marca 2020 r.). Jeszcze do niedawna, przed rozwojem ICT, gdy nie istniały dostępne obecnie formy komunikacji, tego rodzaju przymusowe odosobnienie ( „kwarantanna”) wiązałoby się z zaniechaniem większości codziennych aktywności związanych z pracą zawodową. Z perspektywy czasu widać jednak coraz wyraźniej, że dla znaczącej liczby osób, w tym nas samych, moment ten stał się nie tyle chwilą wyciszenia, ile raczej, używając frazy Eriksena, „tyranią chwili”: niebywałym rozgadaniem, przyspieszeniem życia oraz wzmożeniem cyfrowych interakcji społecznych. Wymuszona sytuacją epidemiczną izolacja społeczna okazała się de facto momentem, w którym byliśmy zmuszeni z większą częstotliwością niż zazwyczaj wpatrywać się w monitory naszych komputerów i smartfonów. Te ciekłokrystaliczne ekrany w niesłychanie szybkim tempie zapełniały się w nowymi informacjami dotyczącymi naszej pracy zawodowej. Mówiąc dosadniej: lockdown świata stworzył okazję dla gwałtownego rozszerzenia się przestrzeni wirtualnej. Doświadczenie to zyskało na ostrości skonfrontowane z koniecznością podejmowania obowiązków o innym wymiarze temporalno-przestrzennym. W naszym przypadku najbardziej wymagająca okazała się opieka nad niespełna siedmioletnią wówczas córką, która ze względu na zamknięcie placówki opiekuńczowychowawczej przebywała $\mathrm{z}$ nami $\mathrm{w}$ domu, spełniającym jednocześnie funkcję sali przedszkolnej, placu zabaw, stołówki, gabinetu oraz auli uniwersyteckiej.

Biorąc pod uwagę przywołane powyżej rozpoznania, w artykule skupimy się na naszym indywidualnym doświadczeniu „czasu kwarantanny dla społeczeństwa", które zostało zdominowane przez efekty oddziaływania technologii ICT, a następnie poddamy je teoretycznemu i krytycznemu opracowaniu. Interesują nas zjawiska obserwowane przez nas w warunkach izolacji społecznej, które, jak sądzimy, składają się na obraz Uniwersytetu wyłaniającego się pod wpływem zmian o charakterze neoliberalnym oraz emocje, jakie $\mathrm{w}$ nas (podmiotach będących częścią tej transformacji) wywołują. Za inspirację posłużą nam ustalenia krytyków społeczeństwa informacyjnego oraz neoliberalnego kapitalizmu.

Oczywiście zdajemy sobie sprawę z tego, że prezentowane przez nas rozpoznania mają charakter częściowy i stronniczy (Clifford 1986) i co więcej, same uwikłane są w mechanizmy, które zamierzają obnażyć. Nieodmiennie podzielamy w tym względzie przekonanie wyrażone przez Stephena Tylera, że „wszyscy jesteśmy współwinnymi, nie stawiającymi oporu współ-twórcami władzy GESTELLu, posłuszni rozkazom, nawet wtedy, gdy wydaje się, że poddajemy je krytyce" (Tyler 1999: 85). Innymi słowy, należy zatem wyraźnie podkreślić, że nasz artykuł staje się częścią procesu, który poddajemy krytycznemu namysłowi. To pokazuje paradoksalną pozycję zajmowaną obecnie przez antropologa krytycznego, którego przedmiotem analizy są neoliberalne mechanizmy funkcjonowania podmiotów społecznych, jakim sam podlega w swojej codziennej praktyce 
akademickiej ${ }^{5}$. Dlatego też, biorąc pod uwagę przywołane powyżej spostrzeżenia, proponowaną $\mathrm{w}$ artykule pracę teorii zmuszeni jesteśmy rozumieć za Michelem Foucaultem w kategoriach politycznych. Innymi słowy, posiłkując się wykładnią myśli Foucaulta przedstawioną przez Annę Burzyńską i Michała Pawła Markowskiego (2006: 538): „Skoro podmiot mówiący złapany jest nieuchronnie w pułapkę władzy, to oznacza to, że niemożliwe jest bezinteresowne (czysto teoretyczne) badanie kultury, które tym samym [...] zmienia się w polityczną interwencję". Inicjowane przez nas „działanie zaczepne” wypływa z przyjęcia postawy odpowiedzialności i troski o dobro wspólne, jakim jest, w naszym przypadku, wiedza naukowa (por. Stiegler 2017). Tym samym mamy nadzieję, że prezentowany przez nas artykuł, który z założenia ma spełniać rolę zaangażowanego eseju, nie zaś „etnografii zarazy", sprowokuje dyskusję, a w jej rezultacie podjęcie działań skierowanych przeciwko obowiązującym współcześnie w Uniwersytecie neoliberalnym reżimom produktywności.

\section{"A teraz prędko, zanim dotrze do nas, że to bez sensu!"6 albo fast science}

W książce The Filter Bubble: What the Internet Is Hiding from You Eli Pariser (2011) przedsiębiorca i aktywista, współtwórca organizacji non-profit Avaaz wspierającej walkę o prawa zwierząt (w tym ludzi) oraz ochronę klimatu, twierdzi, że współcześnie żyjemy w internetowych bańkach informacyjnych (filter bubble), ograniczających i definiujących nasze horyzonty poznawcze. Podobne przekonanie wyraża Tomasz Szlendak (2013: 16-17), powołując się na futurologa Paula Saffo, który używa określenia Personal Media Walled Gardens na oznaczenie mechanizmu konstruowania wirtualnych przestrzeni. Na Facebooku selekcjonujemy wiadomości; usuwając te, które nie zgadzają się z naszymi przekonaniami, tworzymy „przyjazny” nam świat. W analogiczny sposób działają algorytmy Google i Facebooka - podsuwają nam informacje, które odpowiadają naszemu punktowi widzenia i zainteresowaniom. Nasze wyobrażenie rzeczywistości kształtuje się zatem w znaczącym stopniu poprzez pryzmat akceptowanych witryn, blogów, wirtualnych przyjaciół. „W ten sposób - jak twierdzi Szlendak - żyjemy na oddzielnych wyspach na społecznym archipelagu, nastąpiła eksplozja okapsułowanych szczelnie nisz" (Szlendak 2013: 17). Nie sposób zaprzeczyć tej diagnozie. Doświadczenie „czasu kwarantanny dla społeczeństwa”, zdominowane w naszym przypadku w dużej mierze przez technologie ICT, problem ten jednak znacznie wyostrzyło. Lockdown realnego świata utorował drogę procesom nadmuchiwania

5 Temu problemowi w całości poświęcamy artykuł pt. Efekt ślepej plamki. Antropologia krytyczna wobec neoliberalizmu (Songin-Mokrzan, Mokrzan 2020).

${ }^{6}$ Cytat pochodzi z animowanego filmu dla dzieci Madagaskar 2. 
cyfrowych baniek informacyjnych oraz wzmacniał poczucie gwałtownego przyrostu wiedzy. Jakie elementy wspólne posiadały zatem w tym szczególnym czasie nasze własne (zakładamy bowiem, że każdy ma inną) nisze wirtualne?

Już 1 marca 2020 r., na dziesięć dni przed wprowadzeniem „czasu kwarantanny dla naszego społeczeństwa”, czasopismo „Praktyka Teoretyczna” na swoim profilu w serwisie społecznościowym Facebook zamieściło przetłumaczony na język polski komentarz Giorgio Agambena zatytułowany Stan wyjątkowy wywołany nieuzasadniona sytuacją kryzysowa. Felieton ukazał się w oryginale 26 lutego 2020 r. we włoskiej gazecie „Il manifesto”. W komentarzu tym Agamben twierdzi, że ograniczenia nałożone przez rząd włoski na społeczeństwo są „nieproporcjonalne w stosunku do zagrożenia, które jest, według NRC [Włoska Krajowa Rada ds. Badań Naukowych - przyp. autorów], zwyczajną grypą, niewiele różniącą się od tej, która dotyka nas każdego roku" (Agamben 2020). Pośpieszne zaakceptowanie przez Agambena porównania wirusa SARS-CoV-2 do wirusa grypy oraz podjęta przez filozofa krytyka rządu za wprowadzenie kwarantanny włoskiego społeczeństwa wywołały ożywioną dyskusję, w której - na przestrzeni marca udział wzięły i wzięli, by wymienić tu tylko niektóre i niektórych: Jean-Luc Nancy, Roberto Esposito, Divya Dwivedi, Shaj Mohan, Panagiotis Sotiris. Fakt istnienia tej dyskusji odnotowujemy, śledząc posty-wypowiedzi zamieszczane przez „Praktykę Teoretyczną" na jej profilu. Biorąc pod uwagę, że wypowiedzi te sformułowane zostały przez filozofki i filozofów, można by powiedzieć, że następuje szybki przyrost wiedzy. Nasze bańki informacyjne zaczynają się rozrastać w gwałtownym tempie. 28 marca 2020 r. (ponad trzy tygodnie od odnotowania pierwszego przypadku zakażenia koronawirusem na Słowenii i w Polsce), przeglądając facebookową ścianę, dowiadujemy się, że Slavoj Žižek zdążył napisać książkę Pandemic! Covid-19 Shakes the World (Žižek 2020), liczącą ponad 100 stron, na temat wpływu koronawirusa na społeczeństwo. Media w tym dniu podały, że na całym świecie liczba osób dotkniętych koronawirusem wyniosła niemal 600 tysięcy, na terenie Polski odnotowano natomiast ponad 1300 przypadków zakażeń. Produkcja wiedzy zdaje się przyrastać proporcjonalnie do wzrostu zachorowań. Marzec i kwiecień to czas rozprzestrzeniania publikacji dotyczących społecznego wymiaru pandemii. Piszą między innymi Naomi Klein, Judith Butler, Bruno Latour, Catherine Malabou i inni. Dominuje jeden temat: COVID-19 pretekstem do krytyki neoliberalnego kapitalizmu. Wymienienie wszystkich autorów i autorek zabierających głos na ten temat zajęłoby osobny tom ${ }^{7}$. Odnieść można wrażenie, że nie chcąc czekać na zmierzch, filozofki i filozofowie zamienili sowę w gadającą papugę, która będzie w stanie nadążyć za rozgrywającymi się w błyskawicznym tempie wydarzeniami. Staliśmy się świadkami narodzin „szybkiej filozofii”.

Zapanowało niebywałe rozgadanie, zostaliśmy zalani cyfrową literaturą, której, mówiąc szczerze, nie byliśmy w stanie przyswoić. Z jednej strony dlatego, że

7 Wyszukiwarka Google Scholar, po wpisaniu haseł: COVID, anthropology wskazuje około 10000 rekordów (stan na 31.05.2020). 
nasz czas szczelnie wypełniały obowiązki o zupełnie innym wymiarze temporalno-przestrzennym, z drugiej z uwagi na to, że zaś tekstów, których liczba zwiększała się niemal z godziny na godzinę, było zwyczajnie zbyt wiele. Doświadczenie przyrostu informacji w „czasie kwarantanny dla społeczeństwa” trafnie naszym zdaniem opisują słowa Eriksena, który w Tyranii chwili stwierdził, że „charakterystyczne dla życia w społeczeństwie informacyjnym są nadmiar i zgiełk: informacji jest za dużo, a już na pewno wystarczająco dużo dla każdego" (Eriksen 2003: 31). Warto pamiętać, że konstatacja Eriksena tyczy się „zwyczajnego czasu”, nie zaś „szczególnego czasu pandemii COVID-19”, w którym doświadczenie to zostaje wyraźnie spotęgowane.

Należy tu jednoznacznie podkreślić, że świadomość mnożenia się dzięki technologiom informacyjno-komunikacyjnym owej potencjalnej wiedzy, którą z racji wykonywanego zawodu należałoby (choć ze względu na pojawienie się dodatkowych obowiązków zawodowych i prywatnych nie można w sposób synchroniczny) przyswoić, w naszym przypadku, staje się źródłem niepokoju, rodzącego się w wyniku poczucia nienadążania za rzeczywistością. Nie jest to zresztą przypadek. Opisywany fenomen częstokroć wyzwala bowiem negatywne afekty. Dokonując charakterystyki kultury nadmiaru, Szlendak wskazuje na podobną rzecz. Twierdzi on mianowicie, że doświadczanie prędkości i natłoku informacji rodzi problemy natury emocjonalnej i psychicznej: „Zalew wszystkiego męczy i utrudnia życie, powoduje utratę poczucia kontroli i coś, co w literaturze psychiatrycznej określa się mianem technostresu. Jesteśmy skupieni na byciu podłączonym, non-stop pozostajemy w kontakcie. Jesteśmy ustawicznie pobudzeni, zaalarmowani” (Szlendak 2013: 15). Posiłkując się diagnozą Szlendaka, możemy stwierdzić, że „Czas kwarantanny dla społeczeństwa” wiązał się dla nas - autorów tego tekstu z dominującym doświadczeniem technostresu wynikającym z poczucia nadmiernego przyrostu cyfrowej literatury. Podczas gdy głowiliśmy się, jak poradzić sobie z faktem zamknięcia placówki przedszkolnej, przygotowywaliśmy zdalne zajęcia dla studentów i zastanawialiśmy się, jak radzą sobie nasi bliscy, tuż obok, w wirtualnej przestrzeni przyrost wiedzy następował szybciej niż kiedykolwiek. Niemożność włączenia się $\mathrm{w}$ ten nurt wynikająca $\mathrm{z}$ konieczności sprostania nieoczekiwanym obowiązkom rodziła w nas poczucie dojmującej frustracji. A przecież wystarczyło wyłączyć Internet. Na to jednak nie mogliśmy sobie pozwolić.

Wracając jeszcze do przywołanego na początku tego podrozdziału przypadku Agambena, warto wskazać, że wydarzenie, jakim było opublikowanie Stanu wyjątkowego wywołanego nieuzasadniona sytuacją kryzysowa, ujawniło kluczową z punktu widzenia analiz poświęconych statusowi „szybkiej filozofii” kwestię. Odnosząc się do myśli Bernarda Stieglera wyrażonej w książce Wstrząsy. Głupota i wiedza w XXI wieku (2017), można bowiem uznać, że w chwili obecnej (od opublikowania Stanu wyjątkowego... do czasu, w którym piszemy te słowa, upłynęły zaledwie dwa miesiące) wciąż nie jesteśmy w stanie rozstrzygnąć, czy treści wyrażone przez włoskiego filozofa w sławnym już felietonie przyczyniają się do rozwoju wiedzy. Dzieje się tak, ponieważ na tę chwilę nie znamy jeszcze 
dokładnych przyczyn i skutków rozprzestrzeniania się wirusa ani też wielu innych aspektów jego oddziaływania na organizmy żywe. W związku z tym „szybka filozofia” jest w równym stopniu zorientowana na ukazanie prawdy o rzeczywistości, co obarczona ryzykiem błędu. Można zatem pokusić się o stwierdzenie, że tego rodzaju diagnozy mają ten sam nieokreślony status co słynny kot z eksperymentu myślowego Ervina Schrödingera. Dopóki nie upłynie odpowiedni czas pozwalający na zbadanie rozmaitych aspektów zachowania się wirusa, rozpoznanie to jest jednocześnie fałszywe i prawdziwe. Wydaje się zatem, że korzystne i zalecane ze względów poznawczych byłoby jednak spowolnienie procesu wytwarzania wiedzy, zaciągnięcie hamulca i cierpliwe oczekiwanie na zmierzch. Tak się jednak nie stało.

Oczywiście przyczyn tych impulsywnych reakcji jest z pewnością wiele. Mogą wynikać chociażby z palącej potrzeby zrozumienia gwałtownie zmieniającej się rzeczywistości czy być postrzegane w kategoriach strategicznej interwencji polegającej na próbie zdominowania pola dyskursu lub też (co wydaje nam się najbardziej prawdopodobne w przypadku wystąpienia takich badaczy jak Agamben czy Klein) stanowić próbę uprzedzenia działań polityków, którzy jak wynika z doświadczeń kryzysów lat ubiegłych, wykorzystują moment społecznego strachu i frustracji w celu zaostrzenia neoliberalnych reżimów oraz ograniczenia praw i swobód obywatelskich. Nie zmienia to jednak faktu, że oto stoimy wobec rzeczywistości, w której informacja i wiedza namnażają się w tempie wirusa stanowiącego przedmiot prób opisu i zrozumienia.

Rękę na pulsie wydarzeń starają się trzymać nie tylko filozofki i filozofowie. Od pierwszych dni kwietnia (niewiele ponad miesiąc po rozpoznaniu pierwszego przypadku COVID-19 w Polsce) na nasze skrzynki e-mailowe zaczynają przychodzić wiadomości zawierające powiadomienia o naborze artykułów (oraz innych form komunikacji wiedzy naukowej) do książek oraz tomów czasopism (dostępnych online), które zostaną poświęcone szeroko rozumianym antropologicznym, etnograficznym, socjologicznym i kulturoznawczym badaniom społeczno-kulturowego wymiaru pandemii COVID-19. Informacje te zalewają także nasze facebookowe ściany. W każdym przypadku termin składania gotowych artykułów wydaje nam się zatrważająco bliski. I znów zaczynamy odczuwać obawę związaną z przeświadczeniem, że ze względu na zaistniałe okoliczności życiowe ominie nas szansa szybkiego publikowania, które w obliczu zbliżającej się parametryzacji uczelni wyższych ma przecież niebagatelne znaczenie. Charakter tego doświadczenia dobrze oddaje kolejna konstatacja Szlendaka, iż życiu w natłoku informacji towarzyszyć może lęk „przed utratą atrakcyjnych sposobności. W równoległych wszechświatach mnożą się [bowiem - przyp. autorów] niewykorzystane możliwości i zaprzepaszczone okazje. Przegram, jeśli skoncentruję się na jednej rzeczy. Dlatego łapię kilka rzeczy naraz, zalew [cyfrowej informacji - przyp. autorów] mnie do takiego działania przymusza" (Szlendak 2013: 15). Dominujące w tym samym czasie doniesienia medialne także nie nastrajają zbyt optymistycznie. 8 kwietnia ukazuje się informacja: „w ciągu ostatniej doby odnotowano w Polsce 30 zgonów spowodowanych koronawirusem. To najwyższa liczba ofiar 
jednego dnia. Liczba wszystkich chorych na COVID-19 wynosi 5,2 tys, dotychczas zmarło 159 osób. Smutny »rekord « odnotowano również w Wielkiej Brytanii - zmarło 938 osób" (Polsat News). Z pewnym zakłopotaniem konstatujemy, że „rekord” usiłuje pobić nie tylko wirus. Działania środowiska akademickiego, w tym nasze własne, zaczęły przybierać formy analogiczne do tych będących udziałem zaraźliwych patogenów. Można uznać, że nie tylko stoimy wobec faktu wybuchu pandemii COVID-19, lecz jednocześnie mamy do czynienia z pandemią wiedzy cyfrowej.

Reakcje naukowców na zaistniałą sytuację są jak najbardziej zrozumiałe i odzwierciedlają oraz uwydatniają społeczno-kulturowy kontekst, w którym próbuje odnaleźć się współczesna nauka. Świat potrzebuje natychmiastowej diagnozy stanu rzeczy, a naszym zadaniem jest ją dostarczyć. O ile „szybka filozofia” czy też, używając innego określenia, „filozofia na gorąco”, choć niepozbawiona wyraźnych mankamentów, wydaje nam się w gruncie rzeczy zrozumiała i do zaakceptowania - filozofowie zwolnieni są przecież z obowiązku prowadzenia długotrwałych (i niespiesznych) badań etnograficznych - o tyle rodzi się w nas wątpliwość, czy w takich okolicznościach antropologia społeczno-kulturowa (w jej klasycznym rozumieniu) nadal jeszcze ma rację bytu. Refleksje te prowadzą nas tym samym na manowce rozważań dotyczących tożsamości naszej dyscypliny, jej naukowego charakteru, celów i zadań, jakie powinna ona realizować. Czy będąc pod wpływem „tyranii chwili” (przebywając zarazem w izolacji społecznej), jesteśmy w stanie prowadzić systematyczne badania etnograficzne? Czy nie zrzekamy się w ten sposób prawa do długotrwałej obserwacji i skazujemy jednocześnie na popantropologię, którą zdominują wytarte metafory, wydobywane naprędce ze słownika etnologii? Etnografie wymagają przecież długoterminowego pobytu w terenie, co więcej, to procesy pęczniejące w czasie, które w erze zdominowanej przez dyktaturę szybkiej informacji mogą stać się prawdziwym narzędziem oporu. Dlaczego zatem oddajemy je bez walki? A może dziś nie ma już czasu na etnografię czy w ogóle na niespieszną pracę naukową? I czy w dobie zdominowanej przez reżimy produktywności i praktycznie zorientowaną wiedzę ma to jeszcze jakiekolwiek znaczenie?

„Szybka antropologia” zbliża się nadto do publicystyki, która choć niepozbawiona istotnych wartości, staje się w obecnym natłoku zdarzeń i narracji o nich słabo przyswajalna. Czy takie tworzone naprędce impresje (w tym również i ten artykuł, będący przecież jednocześnie krytyką i egzemplifikacją szybkiej nauki) nie są skazane na równie szybkie zapomnienie? Czy komentarze te nie zostaną w krótkim czasie zastąpione kolejnymi „chwilówkami” (impulsywnymi refleksjami tworzonymi pod wpływem aktualnych wydarzeń)? Czy w ten sposób można tworzyć wiedzę antropologiczną rozumianą jako coś trwałego, choć podlegającego renegocjacji i dalszym przekształceniom? Czy nie godzimy się na banalizację antropologii, której znaczenie i tak rozmywa się dziś w niesłychanym tempie, nie tylko poprzez działania polityczne (wykreślenie etnologii z listy dyscyplin naukowych), ale poprzez fakt przydawania przymiotnika „antropologiczny” rozmaitym 
przedsięwzięciom badawczym? Odnieść można wrażenie, że w obliczu pandemii COVID-19, wyraźniej niż kiedykolwiek dotychczas, widać zmieniające się podejście wobec nauki, stymulowane neoliberalną reformą Uniwersytetu. Procesy, którym podlega obecnie świat akademicki, sprzyjają rozwojowi fast science ${ }^{8}$.

\section{Neoliberalne reżimy produktywności}

W czasie pandemii COVID-19 jak w soczewce zaczęły skupiać się rozmaite obsesje i fantazje neoliberalnej formy urządzania (governmentality), na której wyłonienie się w społeczeństwach kapitalistycznych wskazywał już Michel Foucault w Narodzinach biopolityki (2011). Koncepcja ta zakłada, że władza przestaje być domeną jednostki bądź grupy społecznej, lecz zaczyna oddziaływać w sposób rozproszony $\mathrm{z}$ trudnego do zdefiniowania miejsca. W podmiocie społecznym budzi się zaś pragnienie do działania, którego nie postrzega już w kategoriach przymusu, lecz w terminach nieustannego rozwoju osobistego. Charakterystyczne dla tej formy rządzenia jest także i to, że istotną rolę pełni w niej kwantyfikacja rozmaitych domen naszej aktywności, dzięki czemu możliwe jest uekonomicznienie niemal każdej sfery życia społecznego. Zadaniem, jakie rysuje się przed podmiotem, jest realizowanie wyznaczonych celów poprzez sprawne i efektywne zarządzanie sobą oraz dążenie do uzyskania jak najwyższej produktywności, co możliwe jest właśnie poprzez nieustanne monitorowanie, wyrażonego liczbowo, postępu oraz szerzenie się tzw. kultur audytu (por. Strathern 2000; Songin-Mokrzan 2016). W neoliberalizmie podmiot społeczny staje się zatem „przedsiębiorcą samego siebie" (Foucault 2011: 231), zaś jego życie jawi się jako projekt do realizacji (por. Mokrzan 2019). W odniesieniu do zmian, jakim podlega $w$ ostatniej dekadzie Uniwersytet $\mathrm{w}$ Polsce, instrumentarium charakterystycznym dla neoliberalnej formy urządzania są działania takie jak: kwantyfikacja osiągnięć naukowych, algorytmizacja jakości pracy badawczej, parametryzacja uczelni, przyznawanie akredytacji poprzez wzajemną kontrolę i audyt ${ }^{9}$. Istotną rolę odgrywa także szerzący się imperatyw wiedzy działającej w służbie społeczeństwa i gospodarki ${ }^{10}$.

${ }^{8}$ Te niepokojące w naszym przekonaniu tendencje ilustrują także zyskujące coraz większą popularność propozycje wykorzystywania błyskawicznych narzędzi badawczych w rodzaju quick lub rapid ethnography, które - choć wydają się mieć charakter oksymoroniczny - mogą, jak twierdzą ich zwolennicy, pomóc w kontekstach, w których wiedza służyć ma rozwiązywaniu praktycznych problemów lub pomagać w podejmowaniu decyzji (Handwerker 2001).

9 Trzeba wyraźnie podkreślić, że neoliberalną podmiotowość należy postrzegać jako kategorię idealną, swoisty projekt do realizacji, który jednostka konkretyzuje w sposób indywidualny w swoich codziennych działaniach. I choć neoliberalny typ urządzania nie pozostawia podmiotowi zbyt dużo swobody (głównie z uwagi na to, że przekształca on zewnętrzne narzędzia kontroli w indywidualne pragnienie rozwoju osobistego), poszczególne osoby wypracowują własne metody reagowania na zmiany, jakim podlega Uniwersytet.

${ }_{10}$ Postrzeganie nauki jako dziedziny, której wyłącznym celem powinno być rozwiązywanie rozmaitych problemów społecznych i usprawnianie gospodarki, niesie za sobą liczne problemy. Bada- 
W jaki zatem sposób pandemia koronawirusa unaocznia czy też wyostrza oddziaływanie neoliberalnych reżimów rozwoju i produktywności? Przyjrzyjmy się dominującym w świecie mediów cyfrowych reakcjom na fakt wprowadzenia „Czasu kwarantanny dla społeczeństwa”. Zaznaczmy przy tym wyraźnie, że przywołane poniżej zjawiska dotyczą jedynie dotykającej nas bezpośrednio aktywności o charakterze naukowo-badawczym i akademickim.

Już trzy dni od nałożenia przez rząd polski nakazu społecznej izolacji, 14 marca 2020 r., Polskie Towarzystwo Ludoznawcze zamieściło na oficjalnym profilu w serwisie społecznościowym Facebook post promujący akcję zatytułowaną „Zostaję w domu i piszę hasła w Wikipedii”. Komentarz autorstwa „Polska Wikipedia", który został zamieszczony pod postem PTL reklamującym to wydarzenie, należy traktować jako symptomatyczny z punktu widzenia analiz poświęconych neoliberalnym reżimom produktywności: „Popieramy tę postawę! - piszą autorzy komentarza, dodając wymownie - Wiki-kwarantanna najbardziej efektywną z kwarantann" (https://www.facebook.com/ptl1895). Mniej więcej w tym samym czasie rozmaite jednostki naukowe (etnologiczne, socjologiczne, kulturoznawcze, etc.) w całej Polsce wzywają swoich studentów oraz pracowników akademickich za pomocą e-maili, postów w mediach społecznościowych oraz stron internetowych do podejmowania działań badawczych, których celem jest dokumentowanie doświadczenia „czasu kwarantanny dla społeczeństwa”. W momencie gdy z Włoch docierają tragiczne wiadomości (13 marca 2020 r. zmarło 250 osób), my zachęcamy się wzajemnie do zwiększenia naszych mocy produkcyjnych. Przestrzegając przed niebezpieczeństwem zakażenia koronawirusem, mobilizujemy się do prowadzenia obserwacji w środkach komunikacji miejskiej oraz miejscach publicznych (aptekach, sklepach), prowadzenia wywiadów z sąsiadami, pisania pamiętników, tworzenia kart transkrypcyjnych oraz realizowania badań netnograficznych, etc. Podczas gdy kolejne kraje coraz dotkliwiej odczuwają społeczno-gospodarcze skutki pandemii, a na COVID-19 choruje i umiera coraz większa liczba osób, wysiłki społeczności akademickiej koncentrują się na zintensyfikowaniu aktywności zarówno poznawczej, jak i edukacyjnej.

W przestrzeni medialnej pojawiają się nie tylko informacje o organizowanych webinariach, wirtualnych zespołach badawczych, szkoleniach czy konferencjach online. W chwili gdy znaczna liczba ludzi zmuszona jest do dokonania drastycznej reorganizacji swojego dotychczasowego życia (w tym my sami i nasi studenci, którzy zostali zobligowani do opuszczenia akademików oraz stancji i powrotu do swoich rodzinnych miejsc zamieszkania), stajemy również w gotowości do prowadzenia zajęć w formie zdalnej. Nasze skrzynki e-mailowe oraz uniwersyteckie platformy ko-

nia takie mają dostarczać nie tyle wiedzy dla wiedzy (stymulowanej ciekawością poznawczą), ile wiedzy, która ma działać; nie pytać, lecz udzielać odpowiedzi. W kontekście późnokapitalistycznej gospodarki, w jakiej funkcjonuje obecnie Uniwersytet, dla antropologii oznacza to najczęściej prowadzenie „szybkich” badań jakościowych (stawianie wywiadów ponad uczestnictwem), na podstawie których tworzy się uproszczone, krótkie raporty. 
munikacyjne wypełniają się informacjami o możliwościach wzięcia udziału w szkoleniach internetowych z zakresu e-learningu. Przełożeni nie muszą obligować nas do skorzystania $z$ tej oferty, to w nas samych rodzi się chęć, potrzeba i przymus do rozwijania umiejętności prowadzenia atrakcyjnych zajęć wirtualnych, co świadczy o niebywałej mocy neoliberalnego typu urządzania. Odnosząc się do myśli Frédérica Lordona (2012), można powiedzieć, że neoliberalny projekt współliniowości, polegający na uczynieniu czyjegoś pragnienia (kapitalistycznego pracodawcy) naszym własnym (pracowników) pragnieniem, osiąga swoje pełne urzeczywistnienie.

Pomiędzy czynnościami spod znaku „prozy życia niecodziennego" z pełnym zaangażowaniem przygotowujemy sylabusy zajęć zdalnych. Ze względu na zamknięte biblioteki skanujemy dostępne nam fragmenty książek, wyszukujemy w Internecie treści, które można wykorzystać podczas wirtualnych spotkań, opanowujemy obsługę nowych narzędzi i platform e-learningowych, uczestniczymy $\mathrm{w}$ wideokonferencjach. Jednym słowem, zachowujemy się tak, jak gdyby nie działo się nic nadzwyczajnego, zaś większość naszych problemów sprowadza się do przełamywania utrudnień natury technicznej ze sprzętem czy jakością połączeń. A przecież media donoszą, że gdzieś na świecie umierają ludzie. Można zatem uznać, że choć z założenia „czas kwarantanny dla społeczeństwa” powinien stanowić wyciszenie rozmaitych aktywności zawodowych, w dobie dominacji technologii informacyjno-komunikacyjnych staje się on raczej pretekstem do zintensyfikowania naszych akademickich działań. Mniej więcej po miesiącu od przejścia na zdalne nauczanie w cyfrowych rozmowach kuluarowych coraz odważniej zaczyna być wyrażana myśl, że pracujemy więcej niż przed pandemią. Takie same opinie artykułują nasi studenci, których w szybkim tempie zarzuciliśmy nowymi informacjami, zmuszając ich, niejako z pozycji władzy, do zwiększenia swojej produktywności (pogodzenia obowiązków wynikających z powrotem do rodzinnych miejscowości, z pisaniem, raz na tydzień, obszernych esejów oraz uczestniczeniem w ćwiczeniach i wykładach online), co - jak zaczynają komunikować niektórzy - odbija się na ich zdrowiu fizycznym i psychicznym. Doświadczenie „czasu kwarantanny dla społeczeństwa”, jakie stało się naszym (środowiska akademickiego, zarówno pracowników, jak i studentów) udziałem, trafnie puentuje wypowiedź Baudrillarda, którą czynimy także jednym z epigrafów tego artykułu, iż „łatwość komunikacji wraz z nadmiarem informacji stanowią najpoważniejsze zagrożenie dla ludzkich mechanizmów obronnych" (Baudrillard 2009: 84).

Jak się okazuje, nie tylko nie możemy zwolnić, lecz także nie potrafimy zaakceptować „pustki nicnierobienia”. Wyróżniającym się przekazem, jaki dociera do nas $\mathrm{z}$ otchłani Internetu, jest bowiem ten, iż „czas kwarantanny dla społeczeństwa" nie może być czasem straconym. Warto w tym kontekście zwrócić uwagę na właściwą neoliberalnej formie urządzania tendencję do dyfuzji pojęć i praktyk, jaka zachodzi pomiędzy sferą działań ekonomicznych i przestrzenią innych aktywności społecznych (będących jeszcze do niedawna poza wpływem ekonomii). Owa, dostrzegalna w czasie pandemii COVID-19, potrzeba bycia efektywnym (i niepozostawania $\mathrm{w}$ tyle) współgra $\mathrm{z}$ ideą lean management, znaną już od wielu 
lat w kręgach teoretyków i praktyków zarządzania organizacjami. W bardzo dużym uproszczeniu jednym $\mathrm{z}$ istotnych elementów tej koncepcji, mającej na celu zwiększenie produktywności przedsiębiorstwa, jest nieustanne doskonalenie się między innymi poprzez eliminowanie wszelkiego typu marnotrawstwa w postaci niepotrzebnych aktywności, zużytego materiału i narzędzi, niewykorzystanego potencjału pracowników, zasobów i czasu. Kluczem do sukcesu jest zatem hasło: zero waste! Zero marnotrawstwa!

W świecie wytwarzanym przez technologie informacyjno-komunikacyjne dominuje przekonanie, że czasu społecznej izolacji w żadnej mierze nie wolno marnować. Na marginesie dodać można, że ów przymus bycia produktywnym (bez względu na okoliczności) dotyczy w równej mierze pracy akademickiej, jak i sfery przyjemności i relaksu. W bardzo krótkim czasie od rozpoczęcia izolacji nasze bańki informacyjne szybko zaczęły pęcznieć nie tylko od filozoficznych i naukowych komentarzy, ale także od postów, filmów i tekstów, których głównym celem było zapełnienie nieznośnej, z punktu widzenia neoliberalizmu, „pustki nicnierobienia". Rozmaite wydawnictwa otworzyły dostęp do książek i artykułów. Pojawiły się propozycje wirtualnych wycieczek po muzeach i galeriach sztuki, uczestniczenia w przedstawieniach online oraz "podwórkowych" koncertach dostępnych w sieci w przeciągu trzydziestu minut od zakończenia wydarzenia. Można było wysłuchać na żywo wykładów, a nawet ugotować słynne klopsiki z Ikei, których przepis został udostępniony przez skandynawską firmę. Dość szybko okazało się jednak, że skorzystanie z większości wirtualnych ofert spędzania „czasu wolnego" nie będzie możliwe. $Z$ jednej strony dlatego, że jest ich zwyczajnie zbyt dużo, z drugiej zaś dlatego, że równie szybko odkryliśmy, że ów „czas wolny”, ze względu na wzmożoną aktywność zawodową oraz dodatkowe obowiązki opiekuńczo-wychowawcze, także istnieje jedynie w formie wirtualnej ${ }^{11}$ (hipotetycznej).

W czasie kwarantanny „próżnia nicnierobienia” wydaje się nie do wytrzymania. Paradoksalnie kryzys epidemiczny wzmacnia więc, obecny także przed pandemią, przymus rozwoju osobistego i bycia produktywnym, który podmiot narzuca sam sobie, aby wypełnić pustkę i nie pozostać w tyle. A wszystko to dzieje się w momencie, gdy nie możemy być jeszcze pewni, czy świat, jaki do tej pory znaliśmy, nie rozpada się właśnie na naszych oczach. Zamiast przystanąć, pozwolić sobie na odpoczynek od wytwarzania wiedzy i pospieszyć z pomocą, za wartościowe $\mathrm{w}$ świecie akademickim uznawane jest skrupulatne wypełnianie okresu kwarantanny rozmaitymi aktywnościami. W tym kontekście ujawnia się więc także wątpliwy pod względem etycznym aspekt przymusu bycia produktywnym w czasie pandemii, skomentowany ironicznymi memami pojawiającymi się na naszych facebookowych ścianach:

${ }^{11}$ Odwołujemy się tu do podwójnego znaczenia słowa „wirtualny”, którego definicja zamieszczona w Słowniku Języka Polskiego brzmi następująco: „1. stworzony na ekranie komputera, telewizora, w sposób tak realistyczny, że wydaje się rzeczywisty; 2. stworzony w ludzkim umyśle, ale teoretycznie możliwy" (https://sjp.pl/wirtualny). 


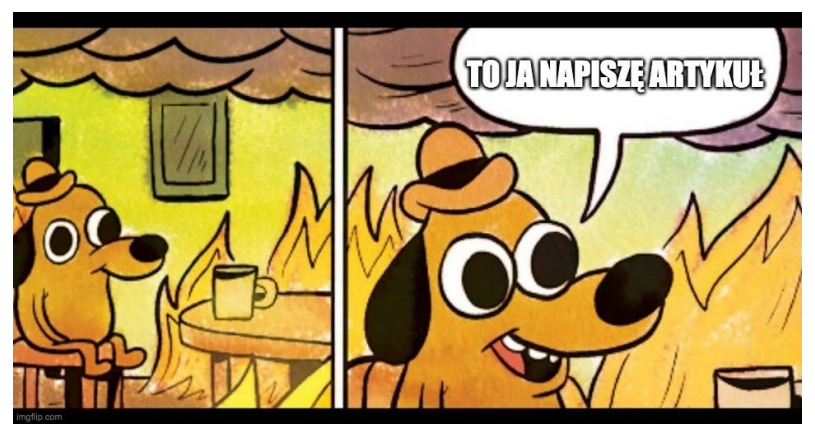

Źródło: https://imgflip.com/i/3x5pjb?fbclid=IwAR0y9AUzG25GV-qvwWrXyzWbEp_ ZqncvjxXfdIyJx4wPqnywqDxYlbRZWHc, dostęp: 29.05.2020.

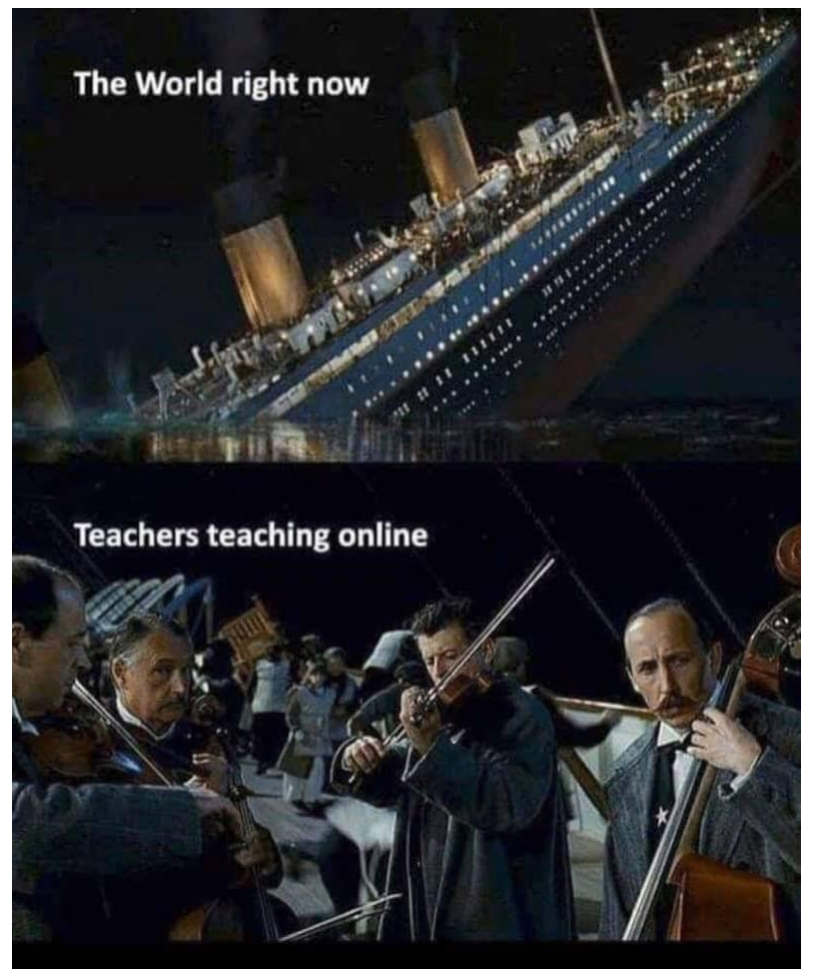

Źródło: https://memezila.com/The-world-right-now-vs-teachers-teaching-online-meme-1481, dostęp: 29.05.2020. 
Naturalnie prezentowany przez nas artykuł, choć spełniać ma w zamyśle rolę zaangażowanego komentarza, zarówno odsłania neoliberalne procesy, jak i wpisuje się w omawiane tu i niepokojące z naszego punktu widzenia, tendencje. Tekst ten można bowiem potraktować par excellence jako fast science oraz jako rezultat pokutującego $\mathrm{w}$ nas imperatywu produktywności. Paradoks ten przyjmuje zatem strukturę chiazmatyczną: będąca przedmiotem naszych dociekań antropologia neoliberalizmu, poprzez odsłonięcie uwikłania podmiotu interpretującego rzeczywistość społeczną (nas samych), przekształca się w neoliberalną antropologię ${ }^{12}$.

Rekapitulując przywołane powyżej rozpoznania, można uznać, że w tym szczególnym „czasie kwarantanny dla społeczeństwa” doświadczaliśmy kształtowania się w przestrzeni naszej codzienności dwóch równolegle istniejących, choć niekompatybilnych, reżimów temporalnych: jednego połączonego z pracą akademicką, drugiego zaś z życiem rodzinnym. Pierwszy z nich powiązany był z wykonywaniem - nie tylko bieżących - obowiązków zawodowych (prowadzeniem zajęć w czasie rzeczywistym za pomocą aplikacji Microsoft Teams), ale także z poszerzaniem wiedzy z zakresu narzędzi zdalnego nauczania. Zachęcano nas jednocześnie do prowadzenia etnograficznych obserwacji dotyczących codzienności w obliczu pandemii, śledzenia naukowych debat poświęconych tej problematyce oraz pisania artykułów. Jednym słowem, pomimo wprowadzenia stanu zagrożenia epidemicznego i społecznej kwarantanny, czas dla pracowników akademickich nie zatrzymał się nawet na moment. Drugi reżim temporalny, związany z wykonywaniem prac domowych i sprawowaniem opieki nad dzieckiem, obligował nas do narzucenia naszej codzienności niespiesznego rytmu. Doświadczenie to dawało poczucie swego rodzaju kompresji czasu, w trakcie którego musieliśmy pomieścić zarówno zawodowe, jak i rodzinne zobowiązania. $\mathrm{W}$ obliczu zbliżającej się parametryzacji i oceny pracowniczej sytuacja ta wymagała od nas także elastycznego i produktywnego zarządzania pojawiającymi się sposobnościami, czego materialnym efektem stał się prezentowany artykuł. Oczywiście, zdajemy sobie także sprawę, że pomimo tej skomplikowanej pod względem logistycznym sytuacji, z uwagi na fakt, iż pracujemy w tym samym zawodzie, zajmujemy bardziej uprzywilejowaną pozycję w stosunku do tych badaczy i badaczek, którzy, z uwagi na rozmaite okoliczności życiowe, nie mogli sobie pozwolić na zabranie głosu w debacie. W pojedynkę zapewne nie byłoby to możliwe.

\section{Pusty ekran monitora}

Co zatem ujawniła pandemia COVID-19 w kontekście dyskusji dotyczącej współczesnego sposobu funkcjonowania Uniwersytetu? Kryzys pandemiczny wyostrzył

12 Szczegółowe rozwinięcie tej kwestii odnajdzie czytelnik w: Mokrzan 2017 oraz Mokrzan 2019: 399-413. 
bez wątpienia fakt, że od pewnego już czasu z dużą intensywnością doświadczamy „wstrząsu, jakim jest wprowadzenie cyfrowego systemu technologicznego w odniesieniu do wszystkich struktur społecznych wywodzących się z nowoczesności" (Stiegler 2017: 110). Wstrząs ten objawia sięw ramach Uniwersytetu szybkim wytwarzaniem i - w coraz bardziej ograniczonym stopniu - konsumowaniem cyfrowej wiedzy naukowej, do której bezpośredni dostęp potęguje doznania nadprodukcji i „nadmiaru” (Baudrillard 2009: 17). Współcześnie, za sprawą technologii informacyjno-komunikacyjnych, wiedza naukowa rozprzestrzenia się z zawrotną (światłowodową) prędkością, a jej rola, jakby powiedział Baudrillard, „sprowadza się do czystej wymienności” (2009: 17).

Proces rozpowszechniania technologii informacyjno-komunikacyjnych w pracy akademickiej posiada dodatkowe reperkusje społeczne. Jak bowiem wskazuje Eriksen w Tyranii chwili:

Dwa ostatnie dziesięciolecia były świadkami niezwykłego rozwoju rozmaitych technologii oszczędzania czasu - od skomplikowanych, wielozadaniowych kalendarzy i notatników po pocztę elektroniczną, pocztę głosową, telefonię komórkową i edytory tekstu - a jednak miliony ludzi bardziej niż kiedykolwiek cierpią dziś na brak czasu. Wygląda to, jakbyśmy nieświadomie stawali się niewolnikami technologii, która miała nas wyzwolić (Eriksen 2003: 5).

Słowa Eriksena zdają się potwierdzać badania, które pokazują, że choć technologie ICT wyręczają nas w wykonywaniu wielu trudnych i uciążliwych czynności zawodowych, znaczna liczba osób odczuwa nieustanne kurczenie się sfery czasu wolnego (Wajcman 2015: 4). Wydaje się, że na ten stan rzeczy wpływają co najmniej dwa czynniki. Z jednej strony, dzięki technologiom informacyjno-komunikacyjnym, nasza praca znajduje się nieustannie na wyciągnięcie ręki. Także jako pracownicy jesteśmy dla naszych przełożonych potencjalnie zawsze dostępni. Nie musimy opuszczać domu, aby realizować powierzone nam obowiązki zawodowe. $\mathrm{Z}$ drugiej zaś strony owa potrzeba nieprzerwanego działania rodzi się w samym podmiocie, który, stymulowany poczuciem chęci dotrzymania tempa pędzącej z zawrotną szybkością rzeczywistości (wyobrażenie to tworzone jest poprzez bezpośredni i natychmiastowy dostęp do informacji), dąży do osiągnięcia jak największej efektywności i produktywności. W realizacji zamierzonych celów pomocne są jednostce rozmaite narzędzia, których zadaniem jest kwantyfikacja własnych codziennych aktywności oraz ciągłe monitorowanie postępów w drodze do samodoskonalenia. Obecnie w sposób bardziej wyraźny niż kiedykolwiek widoczne staje się, że ekspansja neoliberalnej formy urządzania jest nieodmiennie spleciona $\mathrm{z}$ technologiami informacyjno-komunikacyjnymi. Relacja ta ma charakter sprzężenia zwrotnego: neoliberalizm jest warunkiem możliwości rozwoju technologicznego i determinuje jego kierunek, zaś technologie wzmacniają neoliberalną formę urządzania.

W przestrzeni akademickiej pojawiają się, rzecz jasna, krytyczne głosy mające na celu powstrzymanie powyżej opisanych tendencji. Wyraża je między innymi ruch intelektualny określany mianem Slow Science, który w tym kontekście wy- 
daje się nam szczególnie godny zainteresowania. Jak wskazują autorzy The Slow Science Manifesto (2010): „Nauka potrzebuje czasu do namysłu. Nauka potrzebuje czasu na lekturę i czasu na popełnianie błędów. Nauka nie zawsze wie, co aktualnie się dzieje (...). Potrzebujemy czasu na przemyślenia. Potrzebujemy czasu, by przetrawić nasze myśli. Potrzebujemy czasu, aby się wzajemnie nie zrozumieć (...). Nauka potrzebuje czasu" (www.slow-science.org). Jak jednak wynika z obserwowanych działań środowiska akademickiego w czasie pandemii COVID-19, spowolnienie i niespieszne dociekania pozostają (niestety) w odwrocie.

Kończąc prezentowane refleksje, warto, jak sądzimy, zastanowić się nad tym, czy być może dopiero teraz w stosunku do naszego własnego doświadczenia adekwatna okazuje się myśl Baudrillarda dotycząca społeczeństwa informacyjnego, którą pod koniec latach 90. podejrzewaliśmy o nieprzystawanie do polskich realiów. Czy dogoniliśmy „Amerykę” rozumianą, za komentującym Baudrillarda Wolfgangiem Welschem (1998: 209), jako spełnienie się „wszystkich utopii nowoczesności [w tym technologicznych - przyp. autorów], które jednak w trakcie swego spełniania przemieni[ły] się w swoje - a pandemia COVID-19 pozwoliła nam to dostrzec? Jak bowiem pisze Baudrillard:

\footnotetext{
Za sprawą interfejsu rozmówcy podłączają się do siebie niczym wtyczki do kontaktów. Komunikacja następuje w trybie „się”, w zamkniętym obwodzie i bezzwłocznie, a warunkiem sprawnej komunikacji jest błyskawiczne tempo, nie ma bowiem czasu do stracenia, nie ma miejsca na milczenie. W sferze informacji milczenie obłożono zakazem, przegnano ze sfery komunikacji. [...] Milczenie bowiem jest ową mikroskopijną przerwą w obwodzie, cichą katastrofą, błędem, który w przypadku przekazów medialnych zyskuje ważkie znaczenie - zerwaniem obdarzonym potężnym ładunkiem lęku, a zarazem radości, dającym świadectwo temu, iż cała komunikacja nie jest $\mathrm{w}$ istocie niczym innym jak realizacją gotowego scenariusza, nieustannym odgrywaniem fikcji uwalniającym nas od pustki ekranu, i to nie tylko telewizyjnego, ale również mentalnego, na którym z równą fascynacją wypatrujemy kolejnych obrazów. Widok człowieka znieruchomiałego i wpatrzonego w akcie protestu w pusty ekran telewizora będzie kiedyś jednym z najbardziej wymownych obrazów dwudziestowiecznej antropologii (Baudrillard 2009: 17).
}

Parafrazując przywołane powyżej słowa Baudrillarda, można powiedzieć, że widok pracownika akademickiego (a także studenta) znieruchomiałego i wpatrzonego $\mathrm{w}$ akcie protestu w pusty monitor komputera i ekran smartfona byłby jednym z najbardziej wymownych obrazów Uniwersytetu w czasach pandemii COVID-19. Odnieść można jednak wrażenie, że nie skorzystaliśmy z tej możliwości; zaprzepaściliśmy szansę na „nicnierobienie” rozumiane jako akt subwersywny w ujęciu Maurizia Lazzarata. Objaśniając to zagadnienie, Lazzarato (2018) używa sformułowania „leniwe działanie”, które w jego przekonaniu nie oznacza braku działania, lecz „zajęcie [krytycznego - dod. autorzy] stanowiska wobec warunków egzystencji w społeczeństwie kapitalistycznym" (Lazzarato 2018). Podobnie jak Lazzarato - oraz współtwórcy przywołanego powyżej The Slow Science Manifesto - my również uznajemy, że w dobie późnego kapitalizmu w kontekście Akademii „potrzebujemy nie tyle przyspieszenia, ile spowolnienia” (Lazzarato 2018). Nic jednak nie zapowiada, aby ten postulat miał się ziścić, wciąż 
bowiem jesteśmy posłuszni neoliberalnym reżimom produktywności, nawet wtedy, gdy z przekonaniem twierdzimy, że poddajemy je krytycznej analizie.

Czy Uniwersytet, który w dobie kryzysu pandemicznego skoncentrowany jest przede wszystkim na zachowaniu (a w ostatecznym rozrachunku - wzmocnieniu) wskaźników produktywności, w sposób właściwy realizuje misję społeczną? Czy, jak pyta z kolei Cook, w momencie gdy załamują się stabilne dotychczas temporalne architektury (temporal architectures) $)^{13}$, nie powinniśmy de facto zwolnić i zająć się czymś innym? Wydaje się, że w kontekście pandemii COVID-19 bardziej niż kiedykolwiek paląca staje się potrzeba odpowiedzi na pytanie: jaką rolę we współczesnym świecie, zdominowanym przez wstrząsy, katastrofy i kataklizmy (Stiegler 2017: 107), winien pełnić Uniwersytet? Jaką ideę Uniwersytetu powinniśmy wspierać?

\section{Bibliografia}

Agamben G.

2020 Stan wyjątkowy wywołany nieuzasadniona sytuacja kryzysowa, przeł. Ł. Moll, „Praktyka Teoretyczna”,

https://www.facebook.com/PraktykaTeoretyczna/posts/3052401734791796?

tn__=K-R (dostęp: 29.05.2020).

Baudrillard J.

2009 Przejrzystość zła. Esej o zjawiskach skrajnych, przeł. S. Królak, Warszawa.

Burzyńska A., Markowski M.P.

2006 Teorie literatury XX wieku: podręcznik, Kraków.

Clifford J.

1986 Introduction: Partial Truths, w: Writing Culture: The Poetics and Politics of Ethnography, red. J. Clifford, G. Marcus, Berkeley, s. 1-26.

Cook I.M.

2020 Slow. The. Fuck. Down, „Allegra Lab”, https://allegralaboratory.net/slow-thefuck-down/?fbclid=IwAR2vkzyI5gGat_C_hkLGTMjcd3BJn_caQ0T3mjj6dxyGC4qmy6WtCME1c8Y (dostęp: 29.05.2020).

Eriksen T.H.

2003 Tyrania chwili. Szybko i wolno plynacy czas w erze informacji, przeł. G. Sokół, Warszawa.

Foucault M.

2011 Narodziny biopolityki: wykłady w Collège de France 1978-1979, przeł. M. Herer, Warszawa.

Handwerker W.P.

2001 Quick Ethnography: A Guide to Rapid Multi-Method Research, Lanham.

${ }^{13}$ Ian Cook przywołuje w tym miejscu koncepcję Sarah Sharmy (2014). Zdaniem autorki temporalne architektury to niedostrzegane zazwyczaj konglomeraty osób, rzeczy i działań, dzięki którym nasze otoczenie może funkcjonować w znany i przewidywalny sposób. 
Harvey D.

1990 The Condition of Postmodernity: An Enquiry into the Origins of Cultural Change, Cambridge.

Jenks C.

1999 Kultura, przeł. W. Burszta, Poznań.

Lazzarato M.

2018 Wnioski na poczatek. Odmowa pracy, przeł. B. Brzezicka, „Widok. Teorie i Praktyki Kultury Wizualnej” nr 21,

https://www.pismowidok.org/pl/archiwum/2018/21-praca-niewidzialna/wnioski-na-poczatek.-odmowa-pracy (dostęp: 29.05.2020).

Lordon F.

2012 Kapitalizm, niewola i pragnienie: Marks i Spinoza, przeł. M. Kowalska, M. Kozłowski, Warszawa.

Mokrzan M.

2017 Dziesięć wyznań albo krępujący chiazm: od etnografii neoliberalizmu do neoliberalnej etnografii, „Kultura i Społeczeństwo” nr 3, s. 67-86.

Mokrzan M.

2019 Klasa, kapitał i coaching $w$ dobie późnego kapitalizmu. Perswazja neoliberalnego urządzania, Torun.

Pariser E.

2011 The Filter Bubble: What the Internet Is Hiding from You, New York.

Sharma S.

2014 In the Meantime: Temporality and Cultural Politics, Durham, London.

Shore C., Wright S.

2000 Coercive Accountability: The Rise of Audit Culture in Higher Education, w: Anthropological Studies in Accountability, Ethics and the Academy, red. M. Strathern, London, s. $57-89$.

Songin-Mokrzan M.

2016 Transformacja uniwersytetu. „Kultury audytu” i neoliberalne technologie zarzadzania podmiotami społecznymi, „Kultura i Edukacja” nr 3 (113), s. 242-257.

Songin-Mokrzan M., Mokrzan M.

2020 Efekt ślepej plamki. Antropologia krytyczna wobec neoliberalizmu, „Kultura i Społeczeństwo" t. $65 \mathrm{nr} 2$, s. 119-137.

Stiegler B.

2017 Wstrzasy. Głupota i wiedza w XXI wieku, przeł. M. Krzykawski, Warszawa.

Strathern M.

2000 Introduction: New Accountabilities, w: Audit Cultures: Anthropological Studies in Accountability, Ethics, and the Academy, red. M. Strathern, London, s. 1-18.

Szlendak T.

2013 Kultura nadmiaru w czasach niedomiaru, „Kultura Współczesna” nr 1 (76), s. 7-26.

The Slow Science Manifesto

2010 www.slow-science.org (dostęp: 29.05.2020).

Tyler S.

1999 Przed-się-wzięcie post-modernistyczne, przeł. O. Kubińska, W. Kubiński, w: Amerykańska antropologia postmodernistyczna, red. M. Buchowski, Warszawa, s. 67-87.

Wajcman J.

2015 Pressed for Time: The Acceleration of Life in Digital Capitalism, Chicago, London. 
Welsch W.

1998 Nasza postmodernistyczna moderna, przeł. R Kubicki, A. Zeidler-Janiszewska, Warszawa.

\section{Žižek S.}

2020 Pandemic! Covid-19 Shakes the World, New York, London.

Materiały internetowe

Polsat News, https://www.polsatnews.pl/wiadomosc/2020-04-08/koronawirus-raport-dnia-sroda-8-kwietnia/ (dostęp: 13.05.2020).

Słownik Języka Polskiego, https://sjp.pl/wirtualny (dostęp: 29.05.2020).

Polskie Towarzystwo Ludoznawcze, https://www.facebook.com/ptl1895 (dostęp: 29.05.2020).

https://imgflip.com/i/3x5pjb?fbclid=IwAR0y9AUzG25GV-qvwWrXyzWbEp_ ZqncvjxXfdIyJx4wPqnywqDxYlbRZWHc (dostęp: 29.05.2020).

https://memezila.com/The-world-right-now-vs-teachers-teaching-online-meme-1481 (dostęp: 29.05.2020). 